\title{
Adolescents' Perception of the Psychological Security of School Environment, Emotional Development and Academic Performance in Secondary Schools in Gombe Metropolis
}

\author{
Alice K. J. Musa ${ }^{1}$, Bibi Meshak ${ }^{2}$, Jummai Ibrahim Sagir ${ }^{2}$ \\ ${ }^{1}$ Department of Education, Faculty of Education, University of Maiduguri, P. M. B. 1069, Maiduguri, Borno State, \\ Nigeria \\ ${ }^{2}$ Department of Education, Faculty of Education, Gombe State University, Gombe, Nigeria \\ Correspondence: Alice K. J. Musa, Department of Education, Faculty of Education, University of Maiduguri, P. M. B. \\ 1069, Maiduguri, Borno State, Nigeria.
}

Received: May 27, 2016 Accepted: June 12, $2016 \quad$ Online Published: June 30, 2016

doi:10.11114/jets.v4i9.1705 URL: http://dx.doi.org/10.11114/jets.v4i9.1705

\begin{abstract}
The purpose of the study was to determine adolescents' perceptions of the psychological security of their schools environments and their relationship with their emotional development and academic performance in secondary schools in Gombe Metropolis. A sample of 239 (107 males and 133 females) secondary school students selected via stratified random sampling from four public and private secondary schools in Gombe Metropolis participated in the study. A self-develop questionnaire titled "Psychological Perspective of the Security of School Environment, Emotional Development Academic Performance of Adolescents Questionnaire' with a Cronbach Alpha reliability of (.71) was used for the study. Simple Percentage and Multiple Regression were used to analyse the data. The findings reveal that adolescents perceived the psychological security of secondary schools environments as insecure; there are significant relationships between insecurity of school environment with emotional development and academic performance of adolescents. It is recommended that Government and school proprietors should fence all schools, school administrators should provide adequate security for teachers and students through good leadership and parents should train their children well.
\end{abstract}

Keywords: adolescents' perceptions, psychological security, school environment, emotional development, academic performance

\section{Introduction}

Poor school achievement is one of the major concerns of Nigeria just as it has been in other nations globally. Akiri and Ugborugbo (2009) and Bamidele and Bamidele ( 2013) explains that the issues of poor academic performance of students have led to a widely acclaimed fallen standard of education in Nigerian which has become of much concern to most parties involved in the delivery quality of education in the country. GNA $(2009,20102011)$ reported that even though Ghanaian public schools are equipped with professional teachers, available statistics reveals that over 34 public schools in several regions recorded zero per cent pass rate in the 2008 and 2010 of Ghana Basic Education Certificate Examination (BECE). Studies reveal that poor school achievement is not only a concern in its own right but also because it is a predictor of problem behaviours in primary school (Hawkins, Lishner, Catalano, \& Howard 1986) as well as middle (secondary) and senior high (tertiary) schools (Hirschi 1969; Jessor \& Jessor 1977).

While both educationists and psychologists believe that the security of learning environment is very significant in learners' academic performance, psychologists' believe further that the school environment is significant in adolescents' personal growth and development. As a result of these, several productive approaches to determining the psychological safety of the educational environment and its role in personality development and socialization emerged (Rubtsov, 2009; Slobodchikov, 2000). When students feel safe and secure, they are more comfortable in their schools and are better able to learn and succeed, as well as have better opportunities to grow academically, emotionally, and socially (Grogger, 1997).

A safe school environment is a prerequisite for effective learning (Duke \& Stain, 2001) and we posit also for growth 
and development of children. Therefore, for adolescents to perform well in their academics, they must not only be intelligent, motivated and interested in schooling, but must feel safe and protected from physical and emotional threats and or harm in the home, society and most especially the schools environments. The significant of the security in achievement life endeavours is well documented by Abraham Maslow in his hierarchy of needs that safety/security is one of the basic human needs which must be met before one can have the utmost desire and strength to pursue the other higher being needs such as that of intellectual, esthetics and self-actualization needs (Maslow 1954).

Conceptually, the psychological safety/security of the educational environment is the protection of participants from threats to positive development and mental health in the process of the pedagogical interaction and absence of psychotrauma in the communication process, which is the main threat to the psychological safety of participants in the educational environment that can damage positive development and mental health and can also be an obstacle to self-actualization. Pedagogical and interpersonal interactions in the educational environment are psychologically safe if they promote a sense of belonging; convince participants that they are out of danger and strengthen mental health. (Baeva, 2002; Baeva, Volkova, \& Laktionova, 2011; and Bordovskaia 2012). For learning to be meaningful to students therefore, the environment in which it takes place need to be secured. A secure environment is one that ensures emotional security of the learner (Alegre, 2008). Children who grow up in secured environments are likely to develop good emotional regulation (control) and anti-social personality traits (characteristics) which make them to concentrate on learning task ((Verlinden \& Hersen, 2000).

Emotions are outward expressions of inner feelings aroused by one's behaviours or that of others or events (Oladele, 1998). Emotional development is interrelated to physical, cognitive, and social development and affects all aspects of life. Emotions are classified into two categories: pleasant emotions such as joy, enjoyment, happiness, laughter, delight, love, affection, humour, amusement, curiosity; and unpleasant emotions such as fear, anger, depression, grief, envy, hatred, jealousy and so forth. Pleasant emotions facilitate growth, learning and mental health whereas unpleasant emotions inhibits or impedes growth, learning and mental health (Oladele, 1998, Mangal, 2007)

Positive emotions enhance learning by arousing students' attention, concentration motivation, use of learning strategies and self-regulation of learning. Positive emotions draw one's attention towards the object of emotion whereas negative emotion drives one attention from the object of emotion. Thus, when enjoying learning, the task is the object of emotion, making it possible that one's attention is fully focused on the task. Enjoyment can promote students' flow of experiences during learning, such as deep involvement and complete immersion in the activity. By contrast, positive emotions that do not relate to the task can distract attention and reduce performance. For example, fantasies of winning an academic award or spending time with friends may be enjoyable, but can distract attention from one's current homework assignment. However, an important exception is task-related positive emotions, such as enjoyment of learning and excitement about learning materials. These emotions focus attention on the learning task itself rather than drawing it away (Reinhard, 2014).

Negative emotions can strongly obstruct students' learning. Test anxiety, achievement-related hopelessness or boredom during lessons can lead students to withdraw attention, avoid effort, procrastinate in doing assignments, fail exams, and drop out of school. Negative emotions are a major factor explaining why many students do not live up to their potentials and fail to pursue the educational career that would correspond to their abilities and interests (Reinhard, 2014).

Adolescents' emotional development is often characterised by rapidly fluctuating emotions as they are learning to cope with a much larger array of new and unfamiliar situations. Apart from navigating new and uncharted territory, teens growing up in today's society, especially the Nigerian society, are subjected to increased demands on their physical, mental, and emotional resources. Social relationships outside the family have increased with the advent of electronic social networking; academic standards have also become more stringent. Sports and other recreational pursuits are more competitive. Thus while they are learning to cope with these challenges, it should be expected that teens will have a diverse range of emotions (positive and negatives emotions) and may experience fluctuating emotions throughout the day or week (Oswalt, 2010)

Hobson (1986) considers emotional development as growth in the child's ability to distinguish between emotions and to express these emotions in socially acceptable ways and to be able to understand the emotional content of other peoples' communication. Social-emotional development consists of three main areas of children's self regulation: acting (behaving in socially appropriate ways and ways that foster learning); feeling (understanding others' emotions and regulation of one's own emotions, and thinking (regulating attention and thoughts). Any shortcoming in the above areas can impede learning processes. Therefore, Oswalt (2010) explains that adolescents must learn how to respond to new and unfamiliar challenging situations at the same time that they are experiencing increased demands on their physical, mental, and emotional resources which can certainly increase stress.

According to Aggarwal (2011), emotional development plays an important role in the personal and social development 
of an individual. An individual with stable emotional pattern leads a happy, healthy and peaceful life. The individual is at ease with himself and his surroundings. On the other hand an individual who is emotionally disturbed becomes a problem for himself as well as for others. However, continuous threat/disturbance (psychological security) in schools affects individual's emotional growth and development.

Achumba, Ighomereho \& Akpor-Robaro, (2013) report that a positive (secured) school environment is associated with fewer students' behavioural and emotional problems, increased academic success, and higher rates of staff retention which is important for providing a consistent set of adults whom students learn from and others. The reverse may be the case in negative school environments

According to Beland (2005), insecurity is the state of fear or anxiety stemming from a concrete or alleged lack of protection. It refers to lack of or inadequate freedom from danger. This definition reflects physical insecurity which is the most visible form of insecurity, and it feeds into many other forms of insecurity such as economic insecurity social and emotional insecurity. Alegre (2008) conceives environmental insecurity as a feeling of general unease or nervousness or lack of confidence or sense of danger from ones' environment thereby threatening ones self-image, ego and learning.

The issue of insecurity of the school learning environment has become a national emergency challenge which directly or indirectly has affected the emotional development of learners, thus thwarting the achievement of the set of educational goals. The Niger-Delta region of Nigeria has witnessed insecurity challenges around (1990s) which had affected the psychology of the learners emotionally in the learning environment (Olawale, 2014).

\subsection{The Context of the Study}

Starting from 2009-date, the North-East Region of Nigeria, which Gombe State is one, has been experiencing series of insecurity challenges from the Islamist insurgent group known as Boko-Haram, which has not only claimed many lives including those of the children and adolescents but had also led to shut down of schools in many communities. A clear example is the abduction of 276 girls from Government Girls Secondary School in Chibok, Borno State, Nigeria, on the night of $14^{\text {th }}$ of April 2014 (Abubakar, nd), and the attack on Federal Government College Buni-Yardi on $25^{\text {th }}$ February, 2014 (Matazu, 2014), and that of College of Agriculture in Gujiba on $29^{\text {th }}$ September 2013 in which many students were killed and some abducted (Abdulmalik, 2013). Both institutions are in Yobe State, Nigeria. Furthermore, adolescents are the vulnerable group which many politicians use as thugs to advance their political ambitions. These thugs further become a great threat to conducive environment for learning in schools as they terrorise school administrators, teachers and students in and outside school. Hence, there has been a lot of concern on the effects of the psychological security of schools environment by parents, teachers, students and government on students' emotional development and academic achievement.

Prior to the emergence of Boko Haram in the North East, Gombe Metropolis, in particular, has been suffering from insecurity challenges that are bedeviling learning activities in the state in particular from adolescents/youth group known as 'Kalare' group, who have distorted and traumatized crucial activities in the state, moot especially learning among students. Learning activities have also been thwarted by political figures that most times use secondary schools students and school dropped outs as thugs to achieve their political ambitions. Such rival thuggery, when it escalates, schools are normally shut down.

The researchers made four claims as the bases of this study. First, is that the school environment influences human behaviour and academic achievement. The objective properties of the school environment preset the universal "framework" in which individual development and behaviour take place (Panov, 2007). The second claim is that the psychological security of the school environment and its psychological characteristics has significant impact on the personal and professional development as well as academic behaviours and performance of adolescents (Baeva, Volkova, \& Laktionova, 2011; Bordovskaia, 2012; Baeva and Bordovskaia $^{\mathrm{b}}$, 2015) Third, psychological studies have proven that people can develop adequately only in an environment with certain parameters, one of the most significant of which is safety (Baeva, 2002), which is a basic human need (Maslow 1954). This has a key role in providing for the mental health and emotional development of adolescents and their academic achievement. Four, to determine the effects of psychological security of school environment on adolescents' emotional development and academic behaviours and performance, adolescents are the most appropriate persons to seek information from.

\subsection{The Purpose of the Study}

The purposes of the study were to determine the adolescents' perception of the psychological security of the schools environments in Gombe,; the interrelationship between school environment, emotional development and academic performance of adolescents, whether there is significant relationship between the security of the school environment and emotional development of adolescents, and whether there is significant relationship between the security of the 
school environment and adolescents' academic performance. It also sought to determine the greater contributor between psychological security of school environment and emotional development to the variance of perceived academic performance of adolescents.

\subsection{Research Questions}

What is the perception of adolescents of the psychological security of environments of the secondary schools in Gombe?

\subsection{Research Hypotheses}

Three hypotheses were tested in the study are:

Ho1. There are no significant interrelationships between perceived psychological security of the environment, perceived emotional development and perceived academic performance of adolescents in senior secondary school in Gombe Metropolis.

Ho2. There are no significant relationships between perceived security of school environment, emotional development and academic performance of adolescents in senior secondary schools in Gombe metropolis

Ho3. There is no significance difference between perceived psychological security of environment and perceived emotional development of adolescents in their contributions to the variance of academic performance of adolescents in secondary school in Gombe metropolis.

\section{Method}

\subsection{Participants}

The target population for the study comprises all secondary school students in Gombe Metropolis comprising of 63,348 students spread across 90 secondary schools. Stratified random sampling technique was used to select four schools (4) ( 2 public and 2 private) schools out of the 90 secondary schools and simple random sampling was used to select 240 students (107 males and 133 females) for the studies.

\subsection{Instrument}

A self-structured questionnaire title "Psychological Perspective of Security of School Environment, Emotional Development of Adolescents and Academic performance Questionnaire" was used to collect the data. The instrument has 56 items which was divided into 4 sections: Section A is on demographic information of the participants, section B on the nature of security of the school environment with 35 items, section $\mathrm{C}$ is on the effects of security of school environment on emotional development of adolescents (13 items) and section D is on effects of school environment on learning behavior and performance (6 items). The instrument was validated by experts in measurement and evaluation as well psychologists in department of Education University of Maiduguri. It has a Cronbach Alpha reliability of .71, section B .70, section C .70 and section D .59. The response modes are agreed, not sure and disagree. The instrument was self-administered and retrieved without mortality.

\subsection{Method of Data Analysis}

Descriptive statistics of frequency and simple percentage was used to analysed the students perception of the security of the school environment while Standard Multiple Regressions was used to test the significant relationships among the variable as well as the most significant predictor variable of the variance of academic The data was analyse using Special Package for Social Sciences (SPSS)

\section{Results}

In interpreting the results on tables 1-3, on the nature of the psychological security of schools environments, because of the negative effects of insecurity of school environment on students' development generally, a score of $35 \% \%$ and above of the participants who disagreed with a positive statement about the school environment is regarded as indicator of an insecure school environment and where the same percentages disagree with a negative statement about school environment, it is regarded as a secure school environment. On the other hand where $35 \%$ and above of participants are not sure on an item, it is regarded that the nature of the security of the school environment is uncertain 
Table 1. Adolescents' Perception of the Psychological Security of School Environment

\begin{tabular}{|c|c|c|c|c|c|}
\hline S/N0 & Item Statement & $\begin{array}{l}\text { Agree } \\
\text { F }(\%)\end{array}$ & $\begin{array}{l}\text { Not Sure } \\
\text { F }(\%)\end{array}$ & $\begin{array}{r}\text { Disagree } \\
\mathbf{F}(\%)\end{array}$ & $\begin{array}{l}\text { Security } \\
\text { school }\end{array}$ \\
\hline 1 & $\begin{array}{l}\text { In my school, each person (learners, staff and visitor ) feel safe, } \\
\text { supported and secure daily }\end{array}$ & $29(12 \%)$ & $69(29 \%)$ & $142(59 \%)$ & Insecure \\
\hline 2 & $\begin{array}{l}\text { In my school both teachers and learners feel safe in the classroom } \\
\text { because teachers create atmosphere for interaction }\end{array}$ & $121(51 \%)$ & $61(25 \%)$ & $58(24 \%)$ & Secure \\
\hline 3 & Staff in my school present a nurturing environment & $107(45 \%)$ & $72(30 \%)$ & $62(25 \%)$ & Secure \\
\hline 4 & $\begin{array}{l}\text { The management of my school provides security by the use of } \\
\text { security personnel and or detective devices such as cameras to take } \\
\text { track of events }\end{array}$ & $82(34 \%)$ & $89(37 \%)$ & $69(29 \%)$ & Uncertain \\
\hline 5 & $\begin{array}{l}\text { My school is securely safe from unnecessary intruders by fenced and } \\
\text { lockable gate with a security man at the gate }\end{array}$ & $96(40 \%)$ & $77(32 \%)$ & $67(38 \%)$ & Secure \\
\hline 6 & $\begin{array}{l}\text { There are students who bully other students in my school without } \\
\text { being punished** }\end{array}$ & $71(34 \%)$ & $86(36 \%)$ & $73(30 \%)$ & Uncertain \\
\hline 7 & $\begin{array}{l}\text { Some students in my school can attack the principal and staff at the } \\
\text { slightest provocation } * *\end{array}$ & $81(34 \%)$ & $33(14 \%)$ & $126(52 \%)$ & Secure \\
\hline 8 & $\begin{array}{l}\text { In my school, the principal, vice principals and teachers are afraid } \\
\text { of punishing students who commit some kind of offence because they } \\
\text { are afraid of being attack by kalere boys/girls } * *\end{array}$ & $111(46 \%)$ & $55(23 \%)$ & $74(31 \%)$ & Insecure \\
\hline 9 & $\begin{array}{l}\text { The members of the community pass through my school to town } \\
\text { without regards to the school authority and regulations } * *\end{array}$ & $110(46 \%)$ & $40(17 \%)$ & $90(37 \%)$ & Insecure \\
\hline 10 & $\begin{array}{l}\text { The safety committee in my school includes representatives from } \\
\text { teachers, students, parents, administration and discipline master }\end{array}$ & $68(29 \%)$ & $65(27 \%)$ & $107(45 \%)$ & Insecure \\
\hline 11 & My school has good anti-bulling policy that is practice & $18(8 \%)$ & $63(26 \%)$ & $159(66 \%)$ & Insecure \\
\hline 12 & $\begin{array}{l}\text { In my school, the leadership (administrative) support staff, learners } \\
\text { and parents }\end{array}$ & $49(20 \%)$ & $81(34 \%)$ & $109(46 \%)$ & Insecure \\
\hline 13 & $\begin{array}{l}\text { In my school, culture of cooperation - social and emotional skills are } \\
\text { modeled and taught }\end{array}$ & $22(9 \%)$ & $56(23 \%)$ & $162(68 \%)$ & Insecure \\
\hline 14 & My School involves the community and parents in its affairs & $29(12 \%)$ & $55(23 \%)$ & $156(65 \%)$ & Insecure \\
\hline 15 & $\begin{array}{l}\text { My school has a safety committee which include students } \\
\text { membership }\end{array}$ & $15(6 \%)$ & $64(27 \%)$ & $161(67 \%)$ & Insecure \\
\hline 16 & My school has a safety/ emergency preparedness plan in place & $27(11 \%)$ & $66(28 \%)$ & $147(61 \%)$ & Insecure \\
\hline 17 & $\begin{array}{l}\text { My school has an early identification and intervention for students at } \\
\text { risks }\end{array}$ & $36(15 \%)$ & $86(36 \%)$ & $118(49 \%)$ & Insecure \\
\hline 18 & Visitors are not allowed anyhow in my school to see students. ** & $22(9 \%)$ & $54(23 \%)$ & $164(68 \%)$ & Insecure \\
\hline 19 & $\begin{array}{l}\text { Teachers and students are not allow to come to school with things } \\
\text { like razor, knives and nails or metal etc } * *\end{array}$ & $28(12 \%)$ & $49(20 \%)$ & $163(68 \%)$ & Insecure \\
\hline 30 & I have seen your school security plan. & $39(16 \%)$ & $55(33 \%)$ & $146(61 \%)$ & Insecure \\
\hline 21 & My school has an active safety committee. & $53(22 \%)$ & $85(35 \%)$ & $102(43 \%)$ & Insecure \\
\hline 22 & $\begin{array}{l}\text { The safety and emergency response planning in my school includes } \\
\text { emergence personnel such as the fire service, the Police/Civil } \\
\text { Defense army, National Emergency Management Agency (NEMA) } \\
\text { and medical personnel }\end{array}$ & $29(16 \%)$ & $78(33 \%)$ & $123(51 \%)$ & Insecure \\
\hline 23 & My School has a bus for transportation during 1emergency & $69(29 \%)$ & $77(32 \%)$ & $94(39 \%)$ & Insecure \\
\hline 24 & $\begin{array}{l}\text { My school does not allow the use of mobile phone in the schools by } \\
\text { students** }\end{array}$ & $67(28 \%)$ & $67(28 \%)$ & $106(44 \%)$ & Insecure \\
\hline 25 & My school has clearly described responsibilities of staff and students & $22(9 \%)$ & $57(24 \%$ & $161(67 \%)$ & Insecure \\
\hline 26 & $\begin{array}{l}\text { My School has cooperation with safety agency such as NEMA, } \\
\text { Red-Cross society outside the school }\end{array}$ & $22(9 \%)$ & $41(17 \%)$ & $177(74)$ & Insecure \\
\hline 27 & $\begin{array}{l}\text { My school has communication methods to parents and } \\
\text { communalities }\end{array}$ & $36(15 \%)$ & $72(30 \%)$ & $132(55 \%)$ & Insecure \\
\hline 28 & My school has a method of indentifying hazards/potential hazards & $21(9 \%)$ & $52(22 \%)$ & $167(69 \%)$ & Insecure \\
\hline 29 & $\begin{array}{l}\text { The principal of my school keeps us inform of what happens both } \\
\text { inside and outside the school }\end{array}$ & $26(11 \%)$ & $78(32 \%)$ & $136(57 \%)$ & Insecure \\
\hline 30 & My school teaches us safety drill regularly & $15(6 \%)$ & $47(20 \%)$ & $178(74 \%)$ & Insecure \\
\hline 31 & We are very aware of our school surroundings. & $38(15 \%)$ & $65(27 \%)$ & $137(57 \%)$ & Insecure \\
\hline 32 & $\begin{array}{l}\text { There has been attack/boom blast by Boko Haram in the area my } \\
\text { school is located }\end{array}$ & $44(18 \%)$ & $49(215)$ & $147(61 \%)$ & Secure \\
\hline 33 & My school is in area where there are lots of activities of rough boys & $59(25 \%)$ & $65(27 \%)$ & $116(48 \%)$ & Secure \\
\hline 34 & $\begin{array}{l}\text { There is constant fighting where students use knives and other } \\
\text { harmful weapons in my school }\end{array}$ & $52(22 \%)$ & $53(22 \%)$ & $135(56 \%)$ & Secure \\
\hline 35 & $\begin{array}{l}\text { I am always on the alert for escape in terms of Boko Haram/Kalare } \\
\text { gang's attack }\end{array}$ & $44(18 \%)$ & $58(24 \%)$ & $138(58 \%)$ & Secure \\
\hline
\end{tabular}

\section{** Negative statements}

Of the 35 items measuring the nature of the psychological security of the school environment, $51 \%$ of the participants agree that in their schools both teachers and learners feel safe in the classroom because teachers create atmosphere for interaction, $45 \%$ agreed that staff in their schools present a nurturing environment, $40 \%$ agreed that their schools are safe from unnecessary intruders by fence and lockable gates with security watchmen at the gates, $61 \%$ disagreed that there had been attack/bomb blast by Boko Haram in the area where their schools were located, $48 \%$ disagreed that their schools were located in areas where there are lots of activities of rough boys, 56\% disagreed that there has been 
fighting where students use knives and other harmful weapon in their schools, and 58\% disagreed that they are always on the alert for escape in terms of Boko-Haram/kalare boys attack. The responses to these six items signify that the schools environment is secure.

The students are uncertain about the following in their schools: The management of my school provides security by the use of security personal and or detective devices such as cameras to take track of events $(89,37 \%)$ and there are students who bully other students in my school without being punished (86 36\%).

However, the number of items in which the percentage of participants' responses signifies that the schools environments are insecure is more than those which signified that the school environment is insecure. These are: 111(46\%) of the participants affirmed that in their schools, the administrators and teachers are afraid of punishing students who committed some kind of offences for fear of being attack by' 'kalere' boys/girls and $110(46 \%)$ agreed that members of community pass through their schools to town without the slightest regard to school authorities and regulations.

Furthermore, $39 \%$ to $78 \%$ of the participants disagreed with items signifying the psychological safety of the schools environments: $142(59 \%)$ disagreed that in their schools each person - learners and visitors feel safe, supported and secured daily; 159 (66\%) disagreed that their schools have good anti-bully policy that is practice; $167(69 \%)$ disagreed that their schools have a method of detecting hazard/potential hazard; $109(46 \%)$ disagreed that the school leadership support staff, learners and students; 162( 68\%) disagreed that in their schools culture of cooperation, social and emotional skills are modeled and taught; 161( 67\%) disagreed that their schools have a safety committee which include students membership and also that their schools have clearly described responsibilities for staff and students; $118(49 \%)$ disagreed that their schools have an early identification and intervention for students at risks; $163(68 \%)$ disagreed that teachers and students are not allowed to come to school with things like razor, knives and nails or metal and also that visitors are not allowed anyhow in their school to see students; $136(57 \%)$ disagreed that their principals keep them informed of what happen inside and outside the school; 178 (74\%) disagreed that their schools teach them safety skills drills regularly and $123(51 \%)$ disagreed that the safety and emergency planning in their schools include emergency personnel from the Fire Service, Police/Civil Defense, Army, National Emergency Management( NEMA) and medical personnel; 106 (44\%) disagreed that their schools do not allow the use of mobile phone in the school by students; and 147 ( 61\%) disagree that their schools have a safety/emergency preparedness plan in place

On the items boarding on the influence of the community on psychological security of the school environment, the participants disagreed with the following: $132(55 \%)$ disagreed that their schools have communication methods to parents and communities; 156 (65\%) their schools involve the community and parents in their affairs; and 177 (74\%) disagree that their schools have cooperation with safety agency such as NEMA, Red-Cross Society outside the schools.

Examining the perceived psychological security of the school environments results on table 1, the number of responses which indicate that the school environment is insecure compared to those which indicates that the school environment is secure are more and also boarder on real issues which underpins safety of an environment. It is therefore interpreted that the secondary schools environments in Gombe Metropolis are insecure.

Table 2. ANOVA (b): Correlation among Perceived Psychological Security of School Environment, Emotional Development and Academic Performance of Adolescents

\begin{tabular}{|c|c|c|c|c|c|c|}
\hline Mode & & Sum of Squares & df & Mean Square & $\mathrm{F}$ & Sig. \\
\hline 1 & Regression & 286.481 & 2 & 143.241 & 18.153 & $.000(a)$ \\
\hline & Residual & 1862.205 & 236 & 7.891 & & \\
\hline & Total & 2148.686 & 238 & & & \\
\hline
\end{tabular}

The AOVA table shows that the whole model which consists of perceived security of school environment, emotional development and academic performance is statistically significant $[\mathrm{F}(2,236,238)=18.153, \mathrm{P}=.000)]$. The correlation matrix Table 3 reveals that PSSE correlates significantly with PEDASE $r=.422, p=.000$, with PAPASE $r=.298, p$ $=.000$ and PEDASE correlates significantly with PAPASE $\mathrm{r}=.317, \mathrm{p}=.000$

An examination of the standard deviation of the responses of the participants on correlation matrix- table 3 on the variables indicates that there are small variability in adolescents' perception of their PAPASE as there is a small dispersion of the standard deviation from the mean $(\mathrm{M}=10.78, \mathrm{Sd}=3.00)$; and also in their perceived emotional development $(\mathrm{m}=23.12, \mathrm{Sd}=4.91)$. However there is a wide variability in their perceptions of the psychological security of the school environment (PSSE) as is indicated in the wide dispersion of the standard deviation from the mean $(\mathrm{m}=62.28, \mathrm{Sd}=9.23$ ). These variabilities could likely be due to differences in sex, age, classes or types of school. 
Table 3. Correlation Metric of the PAPASE, PSSE, PEDASE

\begin{tabular}{llll}
\hline & PAPASE & PSSE & PEDASE \\
\hline Mean & 10.7824 & 62.2803 & 23.1213 \\
St D. & 3.00468 & 9.23144 & 4.91332 \\
PAPASE & & & \\
PSSE & $.298^{* *}(.000)$ & $.422 * *(.000)$ & \\
PEDASE & $.317)^{* *}(.000$ & & \\
$; *$ Correlation Sig. (1-tailed) &
\end{tabular}

$\mathrm{N}=239 ; * *$ Correlation Sig. (1-tailed)

Table 4. Model Summary: Influence of Psse and Pedase on Papase

\begin{tabular}{|c|c|c|c|c|c|c|c|c|c|c|}
\hline \multirow[t]{2}{*}{ Model } & \multirow[t]{2}{*}{$\mathrm{R}$} & \multirow{2}{*}{$\begin{array}{c}\mathrm{R} \\
\text { Square } \\
\end{array}$} & \multirow{2}{*}{$\begin{array}{l}\text { Adjusted } \\
\text { Square }\end{array}$} & \multirow[t]{2}{*}{$\mathrm{R}$} & \multirow{2}{*}{$\begin{array}{l}\text { Std.Error of the } \\
\text { Estimate }\end{array}$} & \multicolumn{2}{|c|}{ Change Statistics } & & & \\
\hline & & & & & & $\begin{array}{c}c \text { R } \\
\text { Square } \\
\text { Change }\end{array}$ & $\begin{array}{c}\mathrm{F} \\
\text { Change }\end{array}$ & df1 & df2 & $\begin{array}{l}\text { Sig. F } \\
\text { Change }\end{array}$ \\
\hline 1 & $.365(\mathrm{a})$ & .133 & .126 & & 2.80904 & .133 & 18.153 & 2 & 236 & .000 \\
\hline
\end{tabular}

a Predictors: (Constant), PEDASE, PSSE

The standard multiple regression model summary table 3 reveals that the combined influence of PSSE and PEDASE on PAPASE is significant $-13.3 \%\left(\left[\mathrm{R}^{2}=.133 \times 100\right), \mathrm{p}=.000\right.$. An examination of the coefficient table 5 reveals that both PSSE and PEPASE account significantly for the variance of academic performance: PSSE contributes $20 \%$ [B=.065, $(\beta$ $=.199 \times 100), \mathrm{t}=2.978, \mathrm{p}=.003]$ to the variance in perceived academic performance of adolescents while PEDASE account for $23.3 \%[\mathrm{~B}=.143(\beta=.233 \times 100), \mathrm{t}=3.491, \mathrm{P}=.001]$ of variance in perceived academic performance of adolescents. From these contributions it is clear that PSDASE is a greater predictor of students' academic performance and of adolescents than school environment.

Table 5. Coefficients (A): Collective and Individual's Contribution of PSSE and PEDASE to the Variance In PAPASE

\begin{tabular}{|c|c|c|c|c|c|c|c|}
\hline \multirow[t]{3}{*}{ Model } & \multicolumn{2}{|c|}{$\begin{array}{l}\text { Unstandardized } \\
\text { Coefficients }\end{array}$} & \multirow{3}{*}{$\begin{array}{c}\text { Standardized } \\
\text { Coefficients } \\
\text { Beta }\end{array}$} & \multirow[t]{3}{*}{$\mathrm{t}$} & \multirow[t]{3}{*}{ Sig. } & \multicolumn{2}{|c|}{$\begin{array}{l}95 \% \text { Confidence Interval } \\
\text { for B }\end{array}$} \\
\hline & B & Std. Error & & & & Lower & Upper \\
\hline & & & & & & Bound & Bound \\
\hline (Constant) & 3.447 & 1.297 & & 2.658 & .008 & .892 & 6.001 \\
\hline PSSE & .065 & .022 & 199 & 2.978 & .003 & .022 & .108 \\
\hline PEDASE & .143 & .041 & .233 & 3.491 & .001 & .062 & .223 \\
\hline
\end{tabular}

a Predictors:(Constant), PSSE, PEDASE, b Dependent Variable: PAPASE

\subsection{Discussion}

It was found that the schools environments in Gombe are psychologically insecure. Many administrative issues which are vital for guaranteeing security of school environment are not in place. The school authorities do not include teachers, students and discipline masters, in their security and safety committee, nor do they support staff, learners and parents. The model of the culture of cooperation, emotional and social skills are not practice in most schools. Many school administrators do not described clearly the responsibilities of staff and students nor keep staff and students informed of what happens in and out of school. These will keep students in a state of insecurity with a perpetual uneasiness and the fear and anxiety of the unknown. Furthermore, the schools have no control over the intrusion of outsiders since school premises are used as pathway to town without any restrictions by the school authorities at the same time there is not restriction on staff and students from bringing dangerous materials such as knives, razor blade and metal objects to school nor do they include safety and emergency organistions such as Fire Service, Police/Civil Defense, Army and National Emergency Management Agency ( NEMA) in their plans of safety and emergency response. Lack of the foregoing factors in school environments, most especially in an area where people and the Government are working hard to content with insurgency and terrorism, will surely influence students' emotional development and academic performance adversely. It is not surprising that learners, visitors and staff do not feel safe, supported and secure in these insecure schools environments

The schools environments in Gombe are the type that the administrators and teachers are afraid of disciplining students who commit offences for fear of being beaten by a gang called "kalere guys". It will be difficult for any school environment in which the administration and staff are afraid of punishing certain group of students for their personal safety, to create psychological security for its staff and students. Hence, other parameters for creating psychological security of the school environment cannot be put in place because they depend on the types of discipline that is enshrined in school environments.

These findings support Grogger's (1997) explanation that when students feel safe and secure, they are more comfortable in their schools and are better able to learn and succeed, as well as have better opportunities to grow academically, 
emotionally, and socially while the reverse when they feel insecure.

As should be expected from the nature of the foregoing schools environments, the study reveals that there is significant relationship between psychological insecurity of schools environments and emotional development and academic performance of adolescents in Gombe State and also a significant relationship between emotional development of adolescents and their perceived academic performance. These affirm the reports of Duke and Stain (2001) that a safe school environment is a prerequisite for effective learning and growth and development of children. It is not surprising that adolescents' perception of the psychological insecurity of their schools environments relate significantly with their negative emotional development and their poor academic performance

Furthermore, the study reveals that perceived emotional development is a greater predictor of the variance of academic performance of adolescents than their perceived psychological insecurity of the school environment. This confirms the report of previous studies that unpleasant emotions inhibits or impedes growth, learning and mental health (Oladele, 1987, \& Mangal, 2007), as well as the report of Reinhardt (2014) that negative emotions can strongly obstruct students' learning, test anxiety, achievement-related hopelessness or boredom during lessons can lead students to withdraw attention, avoid effort, procrastinate in doing assignments, fail exams. In addition, Negative emotions are a major factor explaining why many students do not live up to their potentials.

\section{Conclusion}

The study determines the adolescents' perception of the psychological security of schools environments, emotional development and academic performance/ behaviour of adolescents. It is concluded that adolescents perceived the secondary schools in Gombe Metropolis as psychologically insecure. Insecurity of the school environment is related to adolescents' emotional development and academic performance adversely; and negative emotions are greater predictors of poor academic performance than the psychological insecurity of schools environments.

It is recommended that government and school proprietors should fence all schools and provide security men to check and keep away unnecessary intruders from school schools. Parents should train their children well and so as to reduced the development of threatening behaviour of children such as the 'kaleri guys' and others in schools. Government need to ensure that they post trained counsellors to schools so they can counsel students who have emotional problems as well as those with low academic performance and also help change the behaviours of 'kalere boys' and other bad gangs in schools thorough behaviour modification. School administrators and teachers should be role model for students in character and performance of their duties. School administrators should endeavour to maintain the psychological security of their schools environment by engaging the community, students and safety and emergency organisations in their safety and security plans, use disciplinary measure that ensure the psychological security of the school environment for effectives development and academic achievement of staff and students.

The weaknesses of the study lies in the fact that it did not consider sex, types of school, class and age differences in adolescents perceptions of the psychological security of the their school environments, emotional development and academic behaviours and performance. Further studies may choose to include these variables.

\section{References}

Abdulmalik, A. (2013). Boko haram gunmen kill many Yobe College of Agriculture students in early morning attack. Agency Report. Online from

http://www.premiumtimesng.com/news/145635-breaking-boko-haram-gunmen-kill-many-yobe-agric-college-stude nts-early-morning-attack.html

Abubakar, A. (2014). FACTSHEET: How many schoolgirls did Boko Haram abduct and how many are still missing? Factsheets \& Guides. Online from

https://africacheck.org/factsheets/factsheet-how-many-schoolgirls-did-boko-haram-abduct-and-how-many-are-still -missing

Achumba, I. C., Ighomereho, O. S., \& Akpor-Robaro, M. O. M. (2013). Security challenges in Nigeria and the implications for business activities and sustainable development. Journal of Economics and Sustainable Development, 4(2), 279- 299.

Aggarwal, J. C. (2011). Psychology of Learning and Development. New Delhi. Shipra Publications.

Akiri, A. A., \& Ugborugbo, N. M. (2009). Teachers's Effectiveness and Students'Academic Performance in

Alegre, A. (2008). Emotional security and its relationship with emotional intelligence (PDF). Virginia Polytechnic Institute and State University. Retrieved 21 November 2012.

Asamu, F. (2006). Ethnic militias and national security. In J. F. Hassan S. Ebele. A (Ed.), Democracy and Development in Nigeria, Social Issues and External Relation, 3. 
Atkin, B., \& Skitmore, M. (2008). Editorial: stakeholder management in construction, Construction Management and Economics, 26(6), 549-555. http://dx.doi.org/10.1080/01446190802142405

Baeva, I. A. (2002). Psyhologicheskaya bezopastnost v obrazovanii [Psychological Safety in Education].St. Petersburg: Soyuz.

Baeva, I. A., Nina, V., \& Bordovskaia, N. V. (2015). The psychological safety of the educational environment and the psychological well-being of Russian secondary school pupils and teachers. Psychology in Russian States of Arts, 8(1), 86-99. http://dx.doi.org/10.11621/pir.2015.0108

Baeva, I. A., Volkova, E. N., \& Laktionova, E. B. (2011). Psyhologicheskaya Bezopastnost v obrazovatelnoisrede: Razvitiye lichnosti [The Psychological Safety of the Educational Environment: The Development of Personality] (I.A. Baeva, Ed.). Moscow, St. Petersburg: Nestor-Istoriya.

Bamidele, M., \& Bamidele, A. (2013). Influence of Cognitive Performance on Mathematics Student's Level of Achievement. International Researcher, 2(1), 142-150.

Beland, D. (2005). The political construction of collective insecurity: from moral panic to blame avoidance and organised irresponsibility. Center for European Studies Working Paper Series, 126.

Bordovskaia, N. V. (2012). Vozmozhnosti obrazovatelnoi sredyi v professionalno-lichnostnom pazvitie studentov [Opportunities in the educational environment for students' professional and personal development]. In Professionalno-lichnostnoe Razvitie Buduschego Petsialista [The Professional and Personal Development of the Future Professional] (pp. 76-91). St. Petersburg: SPbGU.

Crow, L. D., \& Crow, A. (1956). Understanding Our Behaviour. New York: Alfred A Knoff

Dukes, R. L., \& Stein, J. A. (2001). Effects of assets and deficits on the social control of at-risk behavior among youth: a structural equations approach. Youth Society, 32, 337-359. http://dx.doi.org/10.1177/0044118X01032003003

Ghana News Agency (2009 \& 2010). Report

Ghana News Agency (2011) Report

Grogger, J. (1997). Local violence, educational attainment, and teacher pay. NBER Working Paper No. 6003. Cambridge, MA: National Bureau of Economic Research, Inc. http://dx.doi.org/10.3386/w6003

Hawkins, J. D., Lishner, D. M., Catalano, R. F., \& Howard, M. O. (1986). Childhood predictors of adolescent substance abuse: Toward an empirically grounded theory. Journal of Children in Contemporary Society, 18, 11-48. http://dx.doi.org/10.1300/J274v18n01_03

Hirschi, T. (1969). Causes of Delinquency. Berkeley: University of California Press.

Jessor, R., \& Jessor, S. L. (1977). Problem Behavior and Psychological Development: A Longitudinal Study of Youth. New York: Academic Press

Korir, D. K., \& Kipkemboi, K. (2014). The impact of school environment and peer influences on students' academic performance in Vihiga County, Kenya. International Journal of Humanities and Social Science, 5(1), 240.

Mangal, S. K. (2007). Advvaced Educational Psychology. New Delhi: PHI Learning Private Limited.

Maslow, A. H. (1954). Motivation and Personality. New York: Harper.

Matazu, H. K. (2014). Federal Govt. College In Yobe-Dailytrust Newspaper. Online from http://saharareporters.com/2014/02/25/boko-haram-gunmen-kill-40-studentsfederal-govtcollege-yobedailytrust-ne wspaper

Oladele J. O. (1998). Fundamentals of Psychological Foundation of Education: A Handbook for Students and Teachers (4 th ed). Lagos: Johns - Lad Publishers Ltd.

Oswalt, A, M. (2010). Adolescent Emotional Development. Mentalhelp.net Nov 17 Retrieved on 21/7/2016 Online from https://www.mentalhelp.net/contributors/oswalt/

Panov, V. I. (2007). Psychodidaktika Obrazovatelnyich System [The Psychodidactics of Educational Systems]. Moscow: Piter

Public Secondary Schools in Delta State, Nigeria. Stud. Home Comm. Sci., 3(2), 107-113.

Reinhard, P. (2014). Emotions and learning. The International Academy of Education, Educational Series 24, Australia.

Rubtsov, V. V. (2009). Sotsio-Geneticheskya Psychologiya Razvivaushego Obrazovaniya: Deyatelnostnyii Podchod [The Sociogenetic Psychology of Developmental Education: An Activity Approach].Moscow: MGPPU. 
Slobodchikov, V. I. (2000). O ponyatii obrazovatelnoi sredai v constepstii razvivaushego obrazovaniya [The notion of the educational environment in the concept of developmental education]. In Rossiyskaya konferentsiya po ekologicheskoy psihologii [Russian Conference on Ecological Psychology] (pp. 172-176). Moscow: IG-SOTSIN

Verlinden, S., Hersen, M., \& Thomas, J. (2000). Risk factors in school shootings. Clinical Psychology Review, 20(1), 3-56. http://dx.doi.org/10.1016/S0272-7358(99)00055-0

\section{$(\mathrm{cc}) \mathrm{BY}$}

This work is licensed under a Creative Commons Attribution 3.0 License. 